\title{
Effects of Light Quality and Intensity on the Carbon Dioxide Exchange Rate, Growth, and Morphogenesis of Grafted Pepper Transplants during Healing and Acclimatization
}

\author{
Yoonah Jang ${ }^{1,2 \dagger}$, Boheum Mun $^{3 \dagger}$, Taecheol Seo ${ }^{1}$, Jungu Lee ${ }^{1}$, Sangseok Oh ${ }^{1}$, and Changhoo Chun ${ }^{2,4 *}$ \\ ${ }^{1}$ National Institute of Horticultural \& Herbal Science, Rural Development Administration, Suwon 440-706, Korea \\ ${ }^{2}$ Department of Plant Science, Seoul National University, Seoul 151-921, Korea \\ ${ }^{3}$ Research Coordination Division, Rural Development Administration, Suwon 441-707, Korea \\ ${ }^{4}$ Research Institute for Agriculture and Life Sciences, Seoul National University, Seoul 151-921, Korea
}

\begin{abstract}
This study evaluated the influence of light quality and intensity during healing and acclimatization on the $\mathrm{CO}_{2}$ exchange rate, growth, and morphogenesis of grafted pepper (Capsicum annuum L.) transplants, using a system for the continuous measurement of the $\mathrm{CO}_{2}$ exchange rate. C. annuum L. 'Nokkwang' and 'Tantan' were used as scions and rootstocks, respectively. Before grafting, the transplants were grown for four weeks in a growth chamber with artificial light, where the temperature was set at $25 / 18^{\circ} \mathrm{C}$ (light/dark period) and the light period was 14 hours $\cdot \mathrm{d}^{-1}$. The grafted pepper transplants were then healed and acclimatized under different light quality conditions using fluorescent lamps (control) and red, blue, and red + blue light-emitting diodes (LEDs). All the transplants were irradiated for 12 hours per day, for six days, at a photosynthetic photon flux (PPF) of 50,100 , or $180 \mu \mathrm{mol} \cdot \mathrm{m}^{-2} \cdot \mathrm{s}^{-1}$. The higher PPF levels increased the $\mathrm{CO}_{2}$ exchange rate during the healing and acclimatization. A smaller increase in the $\mathrm{CO}_{2}$ exchange rates was observed in the transplants under red LEDs. At a PPF of $180 \mu \mathrm{mol} \cdot \mathrm{m}^{-2} \cdot \mathrm{s}^{-1}$, the $\mathrm{CO}_{2}$ exchange rate of the transplants irradiated with red LEDs was lowest and it was 37\% lower than those irradiated with fluorescent lamps. The $\mathrm{CO}_{2}$ exchange rates of transplants irradiated with blue LEDs was the highest and $20 \%$ higher than those irradiated under fluorescent lamps. The graft take was not affected by the light quality. The grafted pepper transplants irradiated with red LEDs had a lower SPAD value, leaf dry weight, and dry matter content. The transplants irradiated with blue LEDs had longer shoot length and heavier stem fresh weight than those irradiated with the other treatments. Leaves irradiated with the red LED had the smallest leaf area and showed leaf epinasty. In addition, the palisade and spongy cells of the pepper leaves were dysplastic and exhibited hyperplasia. Grafted pepper transplants treated with red + blue LEDs showed similar growth and morphology to those transplants irradiated with fluorescent lamps. These results suggest that high-quality grafted pepper transplants can be obtained by healing and acclimatization under a combination of blue and red lights at a high PPF level.
\end{abstract}

Additional key words: Capsicum annuum L., graft, light emitting diode (LED), photosynthesis, photosynthetic photon flux (PPF)

\section{Introduction}

The use of grafting in fruit and vegetable production has been expanded in order to control pathogens and to enhance the plants' tolerance against abiotic stresses (Louws et al., 2010; Savvas et al., 2010; Schwarz et al., 2010). Highly technical grafting skills and environmental controls during the healing and acclimatization period are required for the successful production of grafted plants. Grafted plants were usually healed and acclimatized in the past under specific environmental conditions such as high relative humidity ( $\mathrm{RH}$ $\geq 95 \%$ ) and low light intensity in order to produce a healthy plant that survived and grew (Mun et al., 2011). However, several recent papers have reported that the photosynthesis, growth, and quality of grafted plants were improved by increasing the light intensity under highly controlled conditions

\footnotetext{
*Corresponding author: changhoo@snu.ac.kr

${ }^{\dagger}$ These authors are contributed equally to this work.

※ Received 2 July 2012; Revised 2 November 2012; Accepted 2 November 2012. This study was supported by National Institute of Horticultural \& Hebal Science, Rural Development Administration, Republic of Korea (Project No. PJ00634503).
} 
during the healing and acclimatization periods (Jang et al., 2011; Nobuoka et al., 2005).

Light is an essential factor for plant growth. Many studies have shown that both the light intensity and the light quality are important for the growth, development, pigmentation, and shape of plants (Amaki and Hirai, 2008; Fukuda et al., 2008; McNellis and Deng, 1995; Schuerger et al., 1997). Various types of artificial light have been used in plant production including fluorescent, metal halide, and high-pressure sodium lamps (Fang and Jao, 2000). In recent years, light emitting diodes (LEDs) have attracted interest as light sources for plant production, because of their features such as small size, low mass, long life, narrow spectral output, and energy conversion efficiency (Brown et al., 1995; Goto, 2011; Massa et al., 2008). LEDs enable the selection of specific wavelengths for a targeted plant response. The use of red LEDs to power photosynthesis has been widely accepted, because red wavelengths (600 to $700 \mathrm{~nm}$ ) are efficiently absorbed by plant pigments. Early LEDs were red, with the most efficient emitting at $660 \mathrm{~nm}$, which is close to one of the absorption peaks of chlorophyll (Massa et al., 2008). When baby leaf lettuce was grown under varying light sources including red, blue, and red + blue LEDs, and fluorescent lamps, the growth was most favorable under the red single wavelength LEDs than the other treatments (Lee et al., 2010). However, blue light also has a variety of important photomorphogenic roles in plants, including stomatal control, $\mathrm{CO}_{2}$ exchange, stem elongation, and phototropism (Massa et al., 2008).

Our study was conducted in order to evaluate the influence of different light qualities of LEDs during the healing and acclimatization period on the photosynthetic characteristics, photomorphogenesis, and growth of grafted pepper transplants using a system for continuous measurement of the photosynthetic rate.

\section{Materials and Methods}

\section{Plant Material and Growing Scions and Rootstocks}

Pepper (Capsicum anmum L.) 'Nokkwang' (Seminis Vegetable Seeds, Inc., Seoul, Korea) and 'Tantan' (Nongwoo Bio Co., Ltd., Suwon, Korea) were used as the scions and rootstocks, respectively, for producing grafted transplants. Scion seeds were sown two days after the rootstock seeds were sown, in order to obtain scion and rootstock with similar stem diameters. Seeds were sown in 72-cell plug trays (W 280 $\times$ L $540 \times$ H 45 mm, Bumnong Co., Ltd., Jeongeup, Korea) filled with commercial growing substrate (BM 2, Berger Group Ltd., St. Modeste, QC, Canada). The planting density was approximately 476 plants $/ \mathrm{m}^{2}$. The plug trays were wrapped with vinyl chloride resin film and then placed in a germination chamber set at a temperature of $28^{\circ} \mathrm{C}$ in order to promote germination. Five days after sowing, the germinated seedlings were overhead-watered and moved to a growth chamber with artificial light (Hanbaek Co., Ltd., Bucheon, Korea). The temperature of the chamber was set at $25 / 18^{\circ} \mathrm{C}$ (light/dark period), where the light period was $14 \mathrm{~h} \cdot \mathrm{d}^{-1}$ and the photosynthetic photon flux (PPF) was approximately 200 $\mu \mathrm{mol} \cdot \mathrm{m}^{-2} \cdot \mathrm{s}^{-1}$ provided by high pressure sodium, metal halide, and fluorescent lamps. The seedlings were bottom-irrigated twice at weekly intervals, once with water and then with anutrient solution (EC $1.4 \mathrm{dS} \cdot \mathrm{m}^{-1}$, 'Hanbang' for seedling, Coseal Co. Ltd., Seoul, Korea).The scion seedlings had a dry weight of $103.5 \pm 3.47 \mathrm{mg}$, an average of 5.28 true leaves, a leaf area of $29.42 \pm 0.67 \mathrm{~cm}^{2}$, and a stem diameter of $1.64 \pm 0.03 \mathrm{~mm}$. The rootstock seedlings had a dry weight of $115.6 \pm 3.09 \mathrm{mg}$, an average of 4.48 true leaves, a leaf area of $24.65 \pm 0.79 \mathrm{~cm}^{2}$, and a stem diameter of $1.54 \pm$ $0.02 \mathrm{~mm}$

\section{Grafting}

Grafting was completed four weeks after sowing the rootstock. Both the scions and rootstocks had five to six unfolded true leaves. Using a razor blade, the epicotyls of the scion and rootstock were cut $1 \mathrm{~cm}$ below the first true leaf. After placing the scion on the rootstock, the grafted position was tightly secured together with an ordinary grafting clip following the slice grafting method (Lee and Oda, 2003).

\section{Healing and Acclimatization of Grafted Pepper Transplants}

A continuous $\mathrm{CO}_{2}$ measurement system with a semi-open multi-chamber was used for the healing and acclimatization of the grafted pepper transplants and the measurement of the $\mathrm{CO}_{2}$ exchange rate (Jang et al., 2011; Mun et al., 2011; van Iersel and Bugbee, 2000). Four light-transmitting boxes (inside dimension of W $350 \times \mathrm{L} 780 \times \mathrm{H} 220 \mathrm{~mm}$, volume of $60 \mathrm{~L}$ ) made of $10 \mathrm{~mm}$-thick acryl plastic were placed in the growth chamber (Hanbaek Co., Ltd., Bucheon, Korea) where the temperature was set at $22^{\circ} \mathrm{C}$. Each healing box had airinlets and outlets, and a tube for drawing air. Each box was also equipped with a heater (hair dryer heater, Kaiser KHD-5207i, My Friend Co., Ltd., Goyang, Korea) and a humidifier (nebulizer, CT-24, Techsin Electronic Co., Ltd., Foshan, China) in order to maintain the temperature and relative humidity inside.

Atmospheric air was drawn in through the inlet of the healing box at an airflow rate of $13.5 \mathrm{~L} \cdot \mathrm{min}^{-1}$ using the air pumps (LP80VC, Youngnam Air Pump Inc., Busan, Korea) and flow meters $\left(15 \mathrm{~L} \cdot \mathrm{min}^{-1}\right.$, Kofloc, Kojima Instruments Inc., Kyoto, Japan), and the air flowed out through the outlet (Mun et al., 2011; Shibuya et al., 2006).Moisture in the air 
was removed using a dehumidifying tube (SWG-A01-18/PP, Asahi Glass Engineering Co., Ltd., Chiba, Japan). The $\mathrm{CO}_{2}$ concentrations of the air at the inlet and the outlet were measured using the $\mathrm{CO}_{2} / \mathrm{H}_{2} \mathrm{O}$ analyzer (LI-7000, Li-Cor Bioscience, St. Lincoln, NE, USA). The gas exchange in each chamber was measured for 2 minutes during a 10minute cycle and the data were recorded for the last five seconds.

All of the sensors were attached to a data logger (CR23X, Campbell Scientific Inc., Logan, UT, USA) with a power relay (SDM-CD16AC 16-channnel AC/DC controller, Campbell
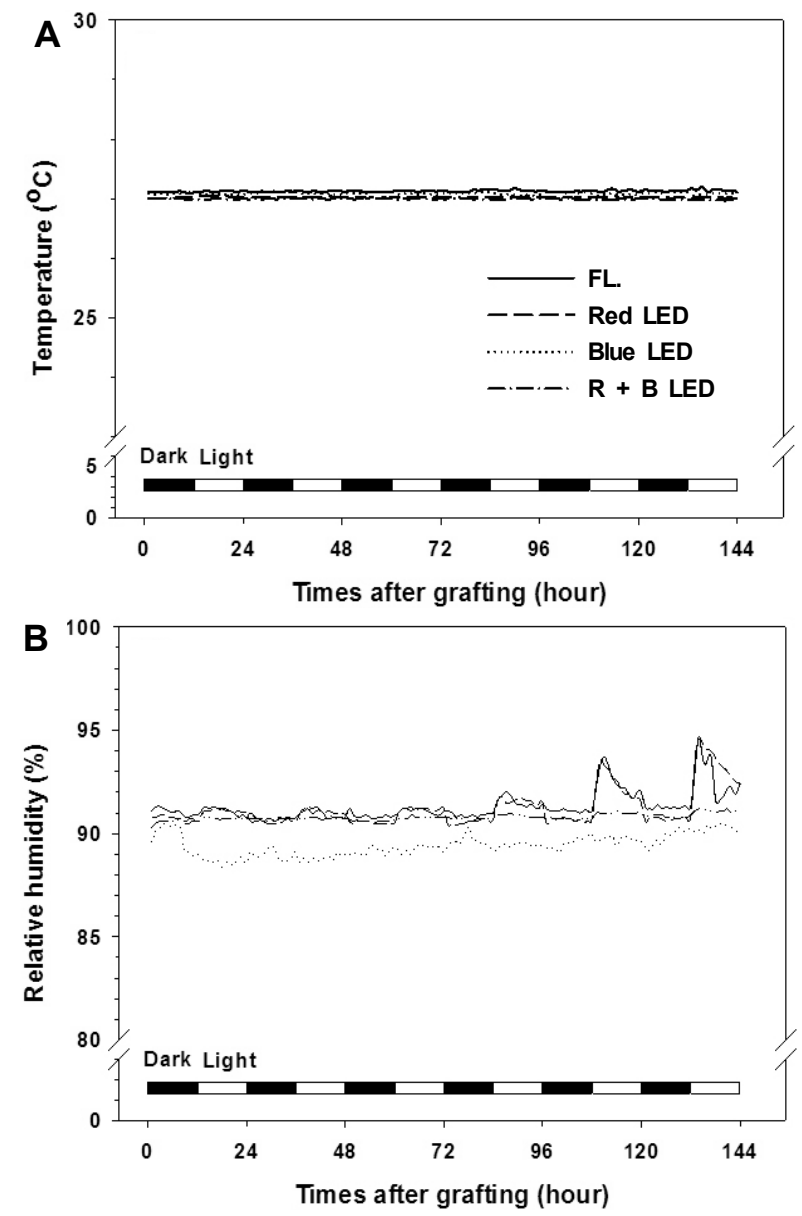

Fig. 1. Time course of the air temperature and relative humidity conditions in light quality treatments during the healing and acclimatization of grafted pepper transplants. The photosynthetic photon flux (PPF) was $100 \mu \mathrm{mol} \cdot \mathrm{m}^{-2} \cdot \mathrm{s}^{-1}$. FL, fluorescent lamps.
Scientific Inc., Logan, UT, USA), switching heaters, humidifiers, fluorescent lamps, and solenoid valves. The temperature and relative humidity inside the box were also measured every hour using a thermocouple (T-types) and a humidity sensor (CHS-UPS, TDK Corp., Tokyo, Japan), respectively. The air temperature in the box was kept at $27^{\circ} \mathrm{C}$ and the relative humidity was maintained at approximately 88 to 94\% (Fig. 1). The healing and acclimatization period lasted for 6 days, during which irrigation was not applied. Afterwards, the grafted pepper transplants were transferred and grown in a glasshouse.

\section{The Lighting System}

The characteristics of the three LED types: red, blue, and red + blue are described in Table 1 . Panel type light sources (W $320 \mathrm{~mm} \times$ L $700 \mathrm{~mm} \times$ H $45 \mathrm{~mm}$, WISE Sensor Inc., Yongin, Korea) of red, blue, or red + blue LEDs were installed approximately $7 \mathrm{~cm}$ above the box. The representative peak wave length and bandwidth, respectively, at half peak height of the red, blue, and red + blue LEDs were 639 and $19 \mathrm{~nm}$ for the red LEDs, 469 and $24 \mathrm{~nm}$ for the blue LEDs, and $640+$ 468 and $20+24 \mathrm{~nm}$ for the red + blue LEDs (Fig. 2). Fluorescent lamps (FL30SSD/29, Dooyoung Lighting Co., Ltd., Seoul, Korea) were used as the control and installed approximately $20 \mathrm{~cm}$ above the box. The light levels were adjusted by changing the number of lamps used. The light intensity and spectral quantum distribution of the light sources

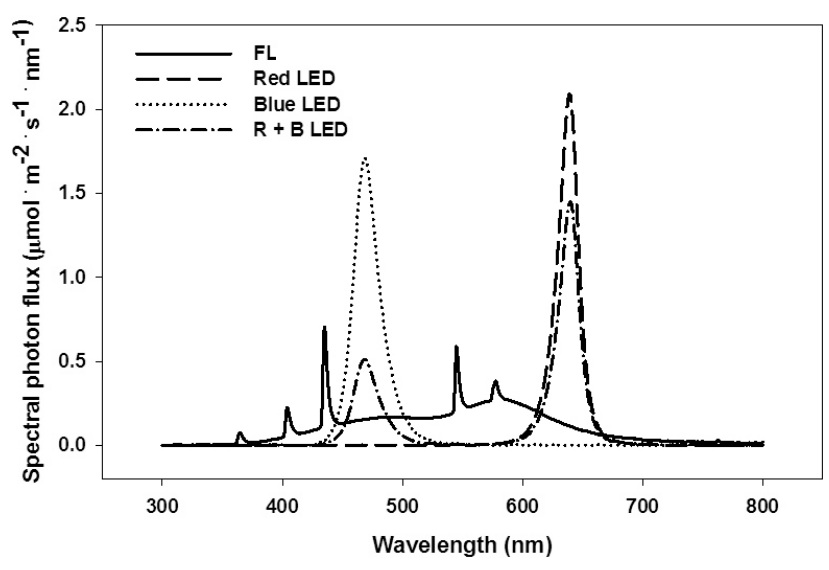

Fig. 2. Spectral distributions of the LEDs and fluorescent lamps $\mathrm{FL}$, fluorescent lamps.

Table 1. Characteristics of the LEDs and fluorescent lamps.

\begin{tabular}{|c|c|c|c|c|c|c|c|}
\hline \multirow{2}{*}{ Light source } & \multicolumn{5}{|c|}{ Relative quantum distribution (\%) } & \multicolumn{2}{|c|}{ Relative quantum ratio } \\
\hline & $300-400$ & $400-500$ & $500-600$ & $600-700$ & $700-800$ & $\mathrm{R} / \mathrm{FR}$ ratio & $\mathrm{B} / \mathrm{R}$ ratio \\
\hline FL & 2.5 & 29.8 & 44.0 & 20.0 & 3.7 & 5.4 & 1.490 \\
\hline Red LED & 0.0 & 0.1 & 1.4 & 98.2 & 0.3 & 290.9 & 0.001 \\
\hline$R+B$ LED & 0.3 & 28.1 & 2.5 & 68.7 & 0.4 & 172.1 & 0.410 \\
\hline Blue LED & 0.1 & 95.0 & 4.9 & 0.0 & 0.0 & 4.9 & 1291.248 \\
\hline
\end{tabular}


were measured above the top of each healing box using a light meter with a quantum light and six sensor bars (Field Scout external light sensor meter, Spectrum Technologies, Inc., Plainfield, IL, USA) and a spectroradiometer (Black Comet CXR-SR-50, StellarNet Inc., Tampa, FL, USA), respectively. The light period was $12 \mathrm{~h} \cdot \mathrm{d}^{-1}$.

\section{Treatment}

During healing and acclimatization, the grafted pepper transplants were irradiated with light with different qualities from the LEDs or fluorescent lamps. All of the transplants were irradiated for $12 \mathrm{~h} \cdot \mathrm{d}^{-1}$ at PPF 50,100 , or $180 \mu \mathrm{mol} \cdot \mathrm{m}^{-2} \cdot \mathrm{s}^{-1}$ (Table 2). The experimental design was a split-plot with PPF as the main plot and light quality as the sub plot. The experiment was repeated twice. In each replication, one 72-cell plug tray with 48 plants was measured.

\section{Measurement of $\mathrm{CO}_{2}$ Exchange Rate and Growth Parameters}

The $\mathrm{CO}_{2}$ exchange rate of each healing box was estimated using the equation noted below with the following parameters: $\mathrm{CO}_{2}$ concentrations, airflow rate to the box, and area of the plug tray:

$\mathrm{CER}=\mathrm{F}\left(\mathrm{C}_{\mathrm{i}}-\mathrm{C}_{\mathrm{o}}\right) / \mathrm{A}$,

where $\mathrm{CER}$ is the $\mathrm{CO}_{2}$ exchange rate in the healing box ( $\mu \mathrm{mol} \mathrm{CO} \mathrm{CO}_{2} \cdot \mathrm{m}^{-2} \cdot \mathrm{s}^{-1}$ ), $\mathrm{F}$ is the air flow rate in the healing box $\left(\mathrm{mol} \cdot \mathrm{s}^{-1}\right), \mathrm{C}_{\mathrm{i}}$ and $\mathrm{C}_{\mathrm{o}}$ are the $\mathrm{CO}_{2}$ concentrations ( $\mu \mathrm{mol} \mathrm{CO}_{2} \cdot \mathrm{mol}^{-1}$ ) in the inlet and outlet of the healing box, respectively, and $A$ is the area of the plug tray $\left(\mathrm{m}^{2}\right)$.

The $\mathrm{CO}_{2}$ generation rates from the growing media and roots were ignored, because they were negligible compared to the exchange rate of the transplants (Shibuya and Kozai, 1998).The graft take and growth parameters, such as fresh weight and stem diameter, were measured on the sixth day after grafting. The leaf area of the true leaves was measured with an area meter (LI-3000, Li-Cor Bioscience, Lincoln, Nebraska, USA). The dry weight was measured after drying the samples at $80^{\circ} \mathrm{C}$. Ten plants in each treatment group were sampled. The data was analyzed using SAS v.9.1 software (SAS Institute, Cary, NC, USA).

Microscopic Observation
The cross sections of the specimens for microscopic observation were prepared as described by Luft (1973). Leaf pieces for measurement of the anatomy were cut off from the young upper leaves of the scions 6 days after grafting. They were infiltrated and fixed in $2.5 \%$ glutaraldehyde in $100 \mathrm{mM}$ phosphate buffer ( $\mathrm{pH} 7.2$ ) for $2 \mathrm{~h}$ at $4^{\circ} \mathrm{C}$. They were then rinsed and post-fixed in $1 \%$ osmium tetroxide for $2 \mathrm{~h}$ at $4{ }^{\circ} \mathrm{C}$ and kept overnight in the phosphate buffer. After fixation, they were dehydrated through a series of graded ethyl alcohol solutions $(40,60,80,90,95$, and $100 \%$ in distilled water $(\mathrm{v} / \mathrm{v}))$. The tissues were further processed with three changes of propylene oxide for 15,15 , and 30 minutes per change, and gradually infiltrated for $3 \mathrm{~h}$ each in 30, 50, and $100 \%$ Eponembedding media in propylene oxide to ensure complete dehydration. They were kept overnight in $100 \%$ Eponand polymerized at $60^{\circ} \mathrm{C}$ for $72 \mathrm{~h}$. They were sectioned $(1,500 \mathrm{~nm})$, stained with periodic acid-Schiff staining (PAS), and viewed under a light microscope (Axioskop 2, Carl Zeiss AG, Oberkochen, Germany).

\section{Results}

\section{$\mathrm{CO}_{2}$ Exchange Rate of Grafted Pepper Transplants}

The $\mathrm{CO}_{2}$ exchange rates of the grafted pepper transplants were near or above zero for two or three days after grafting. Then they gradually increased, averaging $2.9 \mu \mathrm{mol} \mathrm{CO}_{2} \cdot \mathrm{m}^{-2} \cdot \mathrm{s}^{-1}$ on the sixth day (Fig. 3). The $\mathrm{CO}_{2}$ exchange rates were influenced by the light quality and intensity during healing and acclimatization and the rates varied under the different light treatments. During healing and acclimatization, the $\mathrm{CO}_{2}$ exchange rates were higher and increased faster with higher PPF levels.

At a PPF of $50 \mu \mathrm{mol} \cdot \mathrm{m}^{-2} \cdot \mathrm{s}^{-1}$, the $\mathrm{CO}_{2}$ exchange rates on the sixth day ranged from 1.2 (red LED) to $1.7 \mu \mathrm{mol} \mathrm{CO}_{2} \cdot \mathrm{m}^{-2} \cdot \mathrm{s}^{-1}$ (fluorescent lamps) under different light quality conditions. They ranged from 2.4 (blue LED) to 3.5 (fluorescent lamps) at a PPF of $100 \mu \mathrm{mol} \cdot \mathrm{m}^{-2} \cdot \mathrm{s}^{-1}$ and from 3.2 (red LED) to $6.1 \mu \mathrm{mol} \mathrm{CO} \mathrm{CO}_{2} \cdot \mathrm{m}^{-2} \cdot \mathrm{s}^{-1}$ (blue LED) at a PPF of $180 \mu \mathrm{mol} \cdot \mathrm{m}^{-2} \cdot \mathrm{s}^{-1}$. Compared with of the plants irradiated with fluorescent lamps, the $\mathrm{CO}_{2}$ exchange rates on the sixth day of those plants irradiated with red, blue, and red + blue LEDs at

Table 2. Photosynthetic photon flux (PPF) in each light treatment.

\begin{tabular}{lcrrr}
\hline \hline $\begin{array}{l}\text { PPF } \\
\left(\mu \mathrm{mol} \cdot \mathrm{m}^{-2} \cdot \mathrm{s}^{-1}\right)\end{array}$ & Red LED & Blue LED & R + B LED \\
\hline 50 & $56.9 \pm 2.3^{\mathrm{y}}$ & $56.5 \pm 0.9$ & $51.5 \pm 3.7$ & $55.7 \pm 0.5$ \\
100 & $93.0 \pm 4.6$ & $97.3 \pm 3.1$ & $90.3 \pm 1.1$ & $97.8 \pm 0.0$ \\
180 & $182.7 \pm 8.7$ & $183.5 \pm 2.5$ & $177.5 \pm 5.5$ & - \\
\hline
\end{tabular}

${ }^{\mathrm{z}} \mathrm{FL}$, fluorescent lamps.

${ }^{\mathrm{y}}$ Mean \pm S.E. $(\mathrm{n}=2)$. 
a PPF of $50 \mu \mathrm{mol} \cdot \mathrm{m}^{-2} \cdot \mathrm{s}^{-1}$, were 29,7 , and $15 \%$ and the rates were 22,31 , and $11 \%$ lower, respectively, at a PPF of 100 $\mu \mathrm{mol} \cdot \mathrm{m}^{-2} \cdot \mathrm{s}^{-1}$. At a PPF of $180 \mu \mathrm{mol} \cdot \mathrm{m}^{-2} \cdot \mathrm{s}^{-1}$, the $\mathrm{CO}_{2}$ exchange rate of samples irradiated with blue LEDs $\left(6.1 \mu \mathrm{mol} \mathrm{CO} \cdot \mathrm{m}^{-2} \cdot \mathrm{s}^{-1}\right)$ was the highest among the treatments and it was $20 \%$ higher than for those samples irradiated with fluorescent lamps. The $\mathrm{CO}_{2}$ exchange rate of the samples irradiated with red LEDs $\left(3.2 \mu \mathrm{mol} \mathrm{CO} 2 \cdot \mathrm{m}^{-2} \cdot \mathrm{s}^{-1}\right)$ was $37 \%$ lower than those irradiated with fluorescent lamps.

\section{Plant Growth and Morphology}

The grafted pepper transplants irradiated with the red LEDs had a significantly lower leaf areas and leaf dry matter content than the transplants irradiated with the other treatments at PPFs of 100 and $180 \mu \mathrm{mol} \cdot \mathrm{m}^{-2} \cdot \mathrm{s}^{-1}$. At a PPF of $180 \mu \mathrm{mol} \cdot \mathrm{m}^{-2} \cdot \mathrm{s}^{-1}$, the leaf dry weight of the transplants irradiated with the red LEDs was the lowest among the treatments and it was 19\% lower than for the transplants irradiated with fluorescent lamps. The SPAD value of the leaves irradiated with the red LEDs was also lower than that of the leaves irradiated with fluorescent lamps, irrespective of the light intensity.

No difference was observed in the shoot length at a PPF of $50 \mu \mathrm{mol} \cdot \mathrm{m}^{-2} \cdot \mathrm{s}^{-1}$, but the shoot length of the samples irradiated with the blue LEDs was higher than the samples treated with other light sources at PPFs of 100 and $180 \mu \mathrm{mol} \cdot \mathrm{m}^{-2} \cdot \mathrm{s}^{-1}$

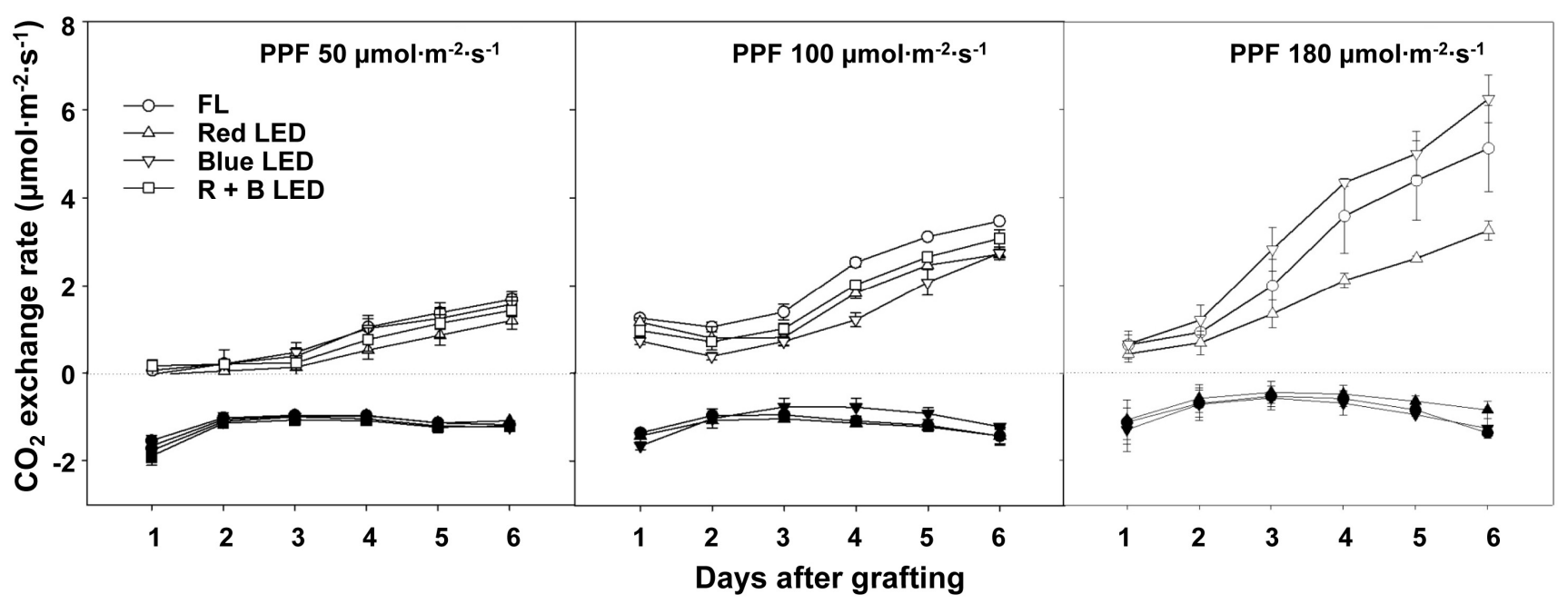

Fig. 3. The effects of light quality and intensity on the $\mathrm{CO}_{2}$ exchange rates of grafted pepper transplants during healing and acclimatization. Open circles represent the $\mathrm{CO}_{2}$ exchange rates during the photo period and closed circles represent the $\mathrm{CO}_{2}$ exchange rates during the dark period. Results are means \pm S.E. $(n=2)$. FL, fluorescent lamps.

Table 3. The effects of light quality and intensity on the growth of grafted pepper transplants during healing and acclimatization on 6 days after grafting.

\begin{tabular}{|c|c|c|c|c|c|c|c|c|c|c|c|c|c|}
\hline \multicolumn{2}{|c|}{ Treatment } & \multirow{2}{*}{$\begin{array}{c}\text { Shoot } \\
\text { length } \\
(\mathrm{cm})\end{array}$} & \multirow{2}{*}{$\begin{array}{l}\text { SPAD } \\
\text { value }\end{array}$} & \multirow{2}{*}{$\begin{array}{l}\text { Leaf } \\
\text { area } \\
\left(\mathrm{cm}^{2}\right)\end{array}$} & \multicolumn{3}{|c|}{ Fresh weight $(\mathrm{mg})$} & \multicolumn{3}{|c|}{ Dry weight (mg) } & \multicolumn{3}{|c|}{ Percent dry matter (\%) } \\
\hline $\begin{array}{l}\text { PPF } \\
\left(\mu \mathrm{mol} \cdot \mathrm{m}^{-2} \cdot \mathrm{s}^{-1}\right)\end{array}$ & $\begin{array}{l}\text { Light } \\
\text { source }\end{array}$ & & & & Root & Stem & Leaf & Root & Stem & Leaf & Root & Stem & Leaf \\
\hline \multirow[t]{4}{*}{50} & $\mathrm{FL}^{\mathrm{z}}$ & $7.9 a^{z}$ & $28.5 \mathrm{a}$ & $33.2 \mathrm{a}$ & $240 \mathrm{~b}$ & $460 \mathrm{~b}$ & $730 \mathrm{a}$ & $18.0 \mathrm{a}$ & $32.5 \mathrm{a}$ & $67.1 \mathrm{a}$ & $7.6 \mathrm{a}$ & $7.0 \mathrm{a}$ & $9.2 \mathrm{a}$ \\
\hline & Red LED & $7.8 \mathrm{a}$ & $25.6 \mathrm{~b}$ & $30.6 \mathrm{a}$ & $296 a$ & $477 \mathrm{~b}$ & 716 a & $20.7 \mathrm{a}$ & 32.9 a & 63.8 a & & 6.9 & $9 \mathrm{a}$ \\
\hline & Blue LED & $8.2 \mathrm{a}$ & $25.6 \mathrm{~b}$ & $32.1 \mathrm{a}$ & 297 a & $523 a$ & 705 a & $20.3 \mathrm{a}$ & $35.7 \mathrm{a}$ & $63.7 \mathrm{a}$ & & $5.8 \mathrm{a}$ & $8.9 \mathrm{a}$ \\
\hline & $\mathrm{R}+\mathrm{B}$ LED & $7.6 \mathrm{a}$ & $26.4 \mathrm{~b}$ & $32.8 \mathrm{a}$ & 308 a & $473 \mathrm{~b}$ & 719 a & $21.0 \mathrm{a}$ & $32.3 \mathrm{a}$ & 65.9 a & $6.9 \mathrm{a}$ & 6.8 a & $9.1 \mathrm{a}$ \\
\hline \multirow[t]{4}{*}{100} & $\mathrm{FL}$ & $6.8 \mathrm{~b}$ & $24.3 \mathrm{a}$ & $31.9 \mathrm{a}$ & $271 \mathrm{a}$ & $465 \mathrm{a}$ & $641 \mathrm{a}$ & $19.8 \mathrm{a}$ & $35.1 \mathrm{a}$ & $59.9 a$ & $7.4 \mathrm{a}$ & $7.6 \mathrm{a}$ & $9.4 \mathrm{a}$ \\
\hline & Red LED & $7.1 \mathrm{ab}$ & $22.8 \mathrm{~b}$ & $27.0 \mathrm{~b}$ & $295 a$ & 492 a & 659 a & $20.2 \mathrm{a}$ & $35.0 \mathrm{a}$ & $55.3 a$ & 6.9 a & & $8.4 \mathrm{~b}$ \\
\hline & Blue LED & $7.4 \mathrm{a}$ & $23.8 \mathrm{ab}$ & $29.6 a b$ & $265 a$ & 466 a & 632 a & $18.7 \mathrm{a}$ & $33.2 \mathrm{a}$ & $58.7 \mathrm{a}$ & $7.4 \mathrm{a}$ & $7.1 \mathrm{a}$ & $9.3 \mathrm{a}$ \\
\hline & $\mathrm{R}+\mathrm{B}$ LED & $7.3 \mathrm{a}$ & $24.9 \mathrm{a}$ & $31.2 \mathrm{a}$ & $246 a$ & 477 a & 638 a & 17.9 a & 34.6 a & $59.4 \mathrm{a}$ & $7.3 \mathrm{a}$ & $7.3 \mathrm{a}$ & $9.3 \mathrm{a}$ \\
\hline \multirow[t]{3}{*}{180} & $\mathrm{FL}$ & $8.2 \mathrm{~b}$ & $28.4 \mathrm{ab}$ & $42.2 \mathrm{a}$ & $265 a$ & $536 \mathrm{~b}$ & 832 a & $18.8 \mathrm{a}$ & $41.6 \mathrm{a}$ & $83.8 \mathrm{a}$ & $7.0 \mathrm{a}$ & $7.8 \mathrm{a}$ & $10.1 \mathrm{a}$ \\
\hline & Red LED & $8.6 \mathrm{~b}$ & $27.4 \mathrm{~b}$ & $33.1 \mathrm{~b}$ & $257 a$ & $573 a b$ & 786 a & $20.4 a$ & $41.6 \mathrm{a}$ & $68.7 \mathrm{~b}$ & $8.1 \mathrm{a}$ & $7.2 a b$ & $8.7 \mathrm{~b}$ \\
\hline & Blue LED & $9.3 \mathrm{a}$ & $29.6 \mathrm{a}$ & $41.0 \mathrm{a}$ & 309 a & $621 \mathrm{a}$ & 845 a & $18.2 \mathrm{a}$ & $41.1 \mathrm{a}$ & $80.2 \mathrm{a}$ & $6.3 \mathrm{a}$ & $6.7 \mathrm{~b}$ & $9.6 \mathrm{a}$ \\
\hline
\end{tabular}

${ }^{\mathrm{z} F L}$, fluorescent lamps.

${ }^{y}$ Different letters indicate a significant difference within a PPF treatment at $p \leq 0.05$ according to Duncan's multiple range test. 
(Table 3). The fresh weight of the stem irradiated with the blue LEDs was also higher than the samples irradiated with the other treatments at PPFs of 50 and $180 \mu \mathrm{mol} \cdot \mathrm{m}^{-2} \cdot \mathrm{s}^{-1}$. No differences were observed in the case of the grafttake, as all of the treatments were close to $100 \%$ (data not shown).

The grafted pepper transplants treated with different light quality and intensity showed different morphologies on the sixth day (Figs. 4 and 5). The transplants irradiated with

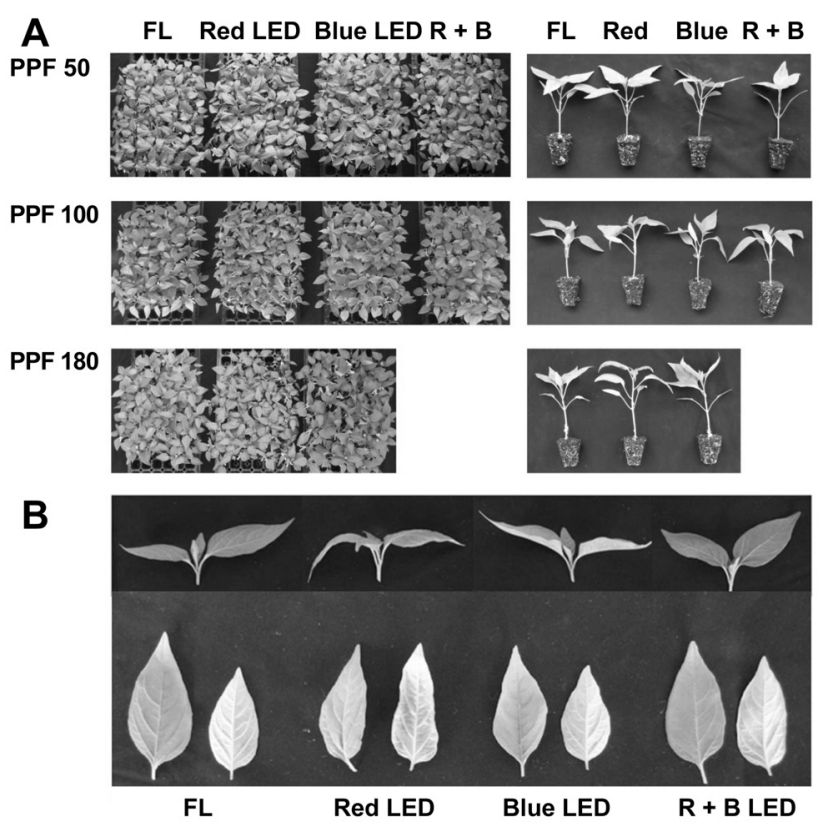

Fig. 4. The effects of light quality and intensity on the morphology of grafted pepper transplants (A) and young upper leaves treated with different light qualities $(B)$ during the six day healing and acclimatization period. The photosynthetic photon flux in (B) was $100 \mu \mathrm{mol} \cdot \mathrm{m}^{-2} \cdot \mathrm{s}^{-1}$. FL, fluorescent lamps. the red LEDs developed abaxially curled (epinastic), young, upper leaves on the third day after grafting. The epinasty became more pronounced over time and under high PPF
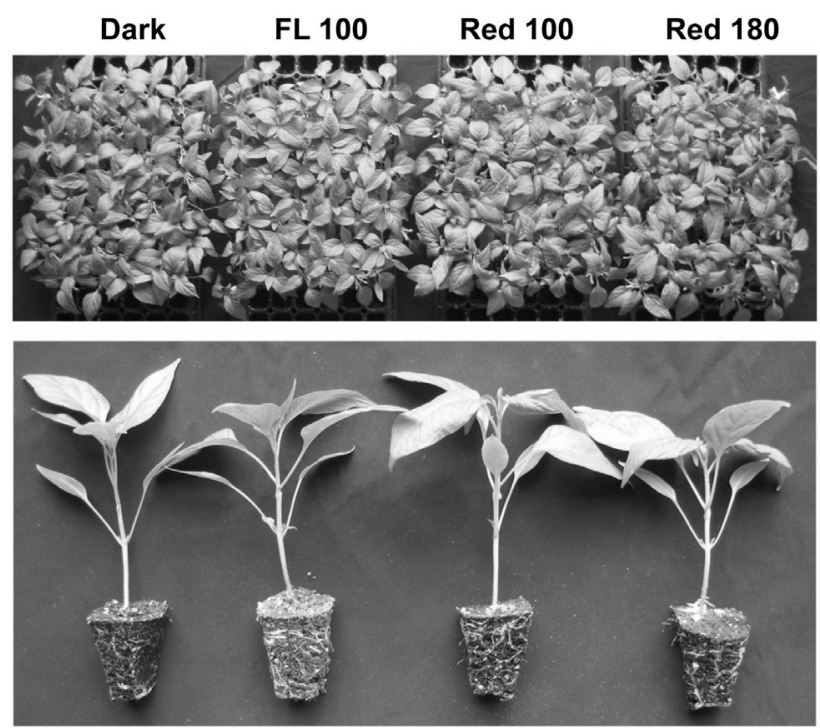

Dark

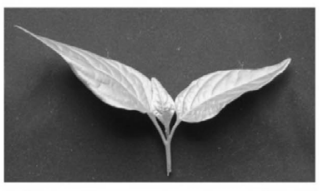

$\mathrm{FL}$
100

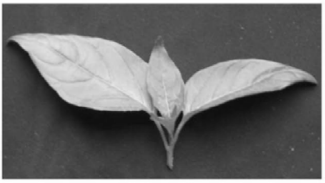

Red

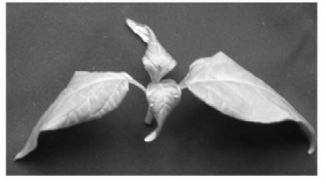

Red

180

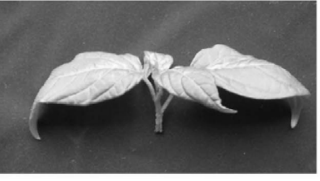

Fig. 5. The effects of light quality and intensity on the morphology of grafted pepper transplants during the six day healing and acclimatization period. FL, fluorescent lamps.

Table 4. The effects of light quality and intensity on the relative growth rate $\left(g \cdot g^{-1} \cdot d^{-1}\right)^{z}$ of grafted pepper transplants during healing and acclimatization.

\begin{tabular}{|c|c|c|c|c|c|c|}
\hline \multicolumn{2}{|c|}{ Treatment } & \multirow{2}{*}{ Root } & \multirow{2}{*}{ Stem } & \multirow{2}{*}{ Leaf } & \multirow{2}{*}{ Shoot } & \multirow{2}{*}{ Entire plant } \\
\hline $\mathrm{PPF}\left(\mu \mathrm{mol} \cdot \mathrm{m}^{-2} \cdot \mathrm{s}^{-1}\right)$ & Light source & & & & & \\
\hline \multirow[t]{4}{*}{50} & $\mathrm{FL}^{\mathrm{y}}$ & $-0.014 a^{x}$ & $-0.004 a$ & $0.010 \mathrm{a}$ & $0.006 a$ & $0.003 \mathrm{~b}$ \\
\hline & Red LED & $0.010 \mathrm{a}$ & $-0.002 a$ & $0.001 \mathrm{a}$ & $0.000 \mathrm{a}$ & $0.003 \mathrm{~b}$ \\
\hline & Blue LED & $0.006 \mathrm{a}$ & 0.009 a & $0.005 \mathrm{a}$ & $0.007 \mathrm{a}$ & $0.017 \mathrm{a}$ \\
\hline & $\mathrm{R}+\mathrm{B}$ LED & $0.010 \mathrm{a}$ & $-0.005 a$ & $0.005 \mathrm{a}$ & $0.002 \mathrm{a}$ & $0.020 \mathrm{a}$ \\
\hline \multirow[t]{4}{*}{100} & $\mathrm{FL}$ & $0.046 \mathrm{a}$ & $0.023 \mathrm{a}$ & $0.021 \mathrm{a}$ & $0.023 a$ & $0.027 \mathrm{a}$ \\
\hline & Red LED & $0.052 a$ & $0.024 a$ & $0.007 \mathrm{a}$ & $0.014 a$ & $0.021 \mathrm{a}$ \\
\hline & Blue LED & $0.037 \mathrm{a}$ & $0.014 \mathrm{a}$ & $0.017 \mathrm{a}$ & $0.017 \mathrm{a}$ & $0.020 \mathrm{a}$ \\
\hline & $\mathrm{R}+\mathrm{B}$ LED & $0.030 \mathrm{a}$ & $0.022 \mathrm{a}$ & $0.020 \mathrm{a}$ & $0.021 \mathrm{a}$ & $0.023 a$ \\
\hline \multirow[t]{3}{*}{180} & $\mathrm{FL}$ & $0.006 \mathrm{a}$ & $0.018 a$ & $0.086 a$ & $0.060 \mathrm{a}$ & $0.053 \mathrm{a}$ \\
\hline & Red LED & $0.017 \mathrm{a}$ & $0.018 a$ & $0.044 \mathrm{~b}$ & $0.035 \mathrm{~b}$ & $0.033 a$ \\
\hline & Blue LED & $0.007 \mathrm{a}$ & $0.018 a$ & $0.079 a$ & $0.055 a$ & $0.048 \mathrm{a}$ \\
\hline
\end{tabular}

${ }^{2}$ Relative growth rate $=\left(\ln w_{2}-\ln w_{1}\right) /\left(t_{2}-t_{1}\right)$, where $w_{2}$ and $w_{1}$ represent the last and initial dry weight $(g)$ and $\left(t_{2}-t_{1}\right)$ represents the experimental time (day).

${ }^{\mathrm{y}} \mathrm{FL}$, fluorescent lamps.

${ }^{x}$ Different letters indicate a significant difference within a PPF treatment at $p \leq 0.05$ according to Duncan's multiple range test. 
conditions. Blue LEDs elongated the stem of the plants especially at a PPF of $180 \mu \mathrm{mol} \cdot \mathrm{m}^{-2} \cdot \mathrm{s}^{-1}$. The characteristics of the leaves treated with red + blue LEDs were similar with those under fluorescent lamps.

The relative growth rates (RGRs) of the leaf, shoot, and the entire plant increased under high PPF conditions (Table 4). At a PPF of $50 \mu \mathrm{mol} \cdot \mathrm{m}^{-2} \cdot \mathrm{s}^{-1}$, the RGRs of the entire plants irradiated with blue and red + blue LEDs were higher than those irradiated with fluorescent lamps and red LEDs. A difference in the RGRs was not observed at a PPF of $100 \mu \mathrm{mol} \cdot \mathrm{m}^{-2} \cdot \mathrm{s}^{-1}$, but the RGRs of the leaves irradiated with the red LEDs were the lowest at a PPF of $180 \mu \mathrm{mol} \cdot \mathrm{m}^{-2} \cdot \mathrm{s}^{-1}$.

\section{Leaf Anatomical Differences}

The distribution of the palisade and spongy mesophyll cells of the grafted pepper transplants' young upper leaves varied under different light treatments during the six day healing and acclimatization period (Fig. 6). The palisade cells and spongy cells of the pepper leaves irradiated with the LEDs were aligned more densely than those of the pepper leaves irradiated with the fluorescent lamps. The palisade tissue cells of the pepper leaves irradiated with the red LEDs were most densely aligned and there was barely any empty space among the cells. The lacunae in the spongy mesophyll tissue were smaller in size in the pepper leaves grown under the LEDs, especially red LEDs, than the pepper leaves grown under the fluorescent lamps. The edge of the leaves irradiated with red LEDs were also curled more downward than those irradiated with other treatments.

\section{Discussion}

Healing and acclimatization are critical processes for grafted plants to survive. Light intensity, relative humidity, and temperature are the key environmental factors that influence the healing and acclimatization of grafted transplants. During healing and acclimatization, PPF affected the photosynthesis, growth, and quality of the grafted transplants, with a high PPF improving these characteristics (Jang et al., 2011).

At the present time, LEDs are used in plant production because of their various merits. Early LEDs were red because they were regarded to have great potential for driving photosynthesis (Massa et al., 2008). However, there have been reports of a reduction in photosynthesis and growth under red LEDs alone in wheat, rice, radish, lettuce, and spinach (Goins et al., 1997; Matsuda et al., 2004; Yorio et al., 2001). These reports noted that the combination of red and blue light was an effective light source for several crops.

In this study, the $\mathrm{CO}_{2}$ exchange rates of grafted pepper transplants irradiated with red LEDs were lower than those irradiated with other treatments at PPFs of 50 and $180 \mu \mathrm{mol} \cdot \mathrm{m}^{-2} \cdot \mathrm{s}^{-1}$. At a PPF of $180 \mu \mathrm{mol} \cdot \mathrm{m}^{-2} \cdot \mathrm{s}^{-1}$, the $\mathrm{CO}_{2}$ exchange rates of the grafted pepper transplants irradiated with blue LEDs was the highest. Liu et al. (2011) reported that the net photosynthesis of cherry tomato plants decreased under red LEDs and increased under the light treatments with blue, red + blue, and red + blue + green LEDs with a PPF of $320 \mu \mathrm{mol} \cdot \mathrm{m}^{-2} \cdot \mathrm{s}^{-1}$.

Tennessen et al. (1994) reported that the photosynthesis
FL

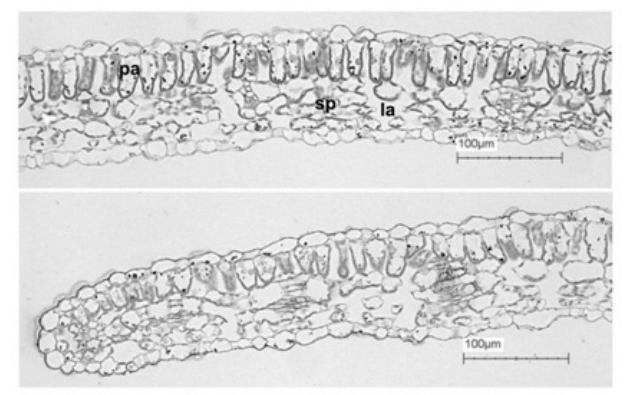

Blue
LED

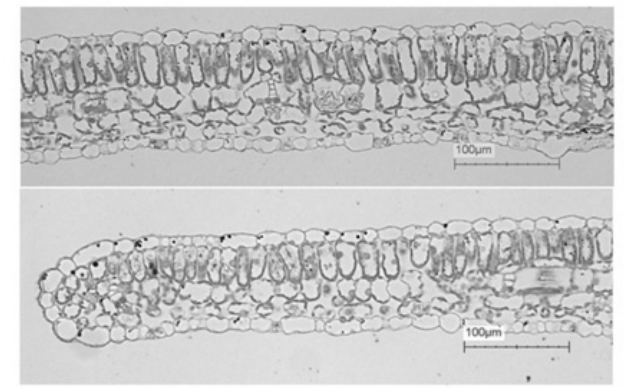

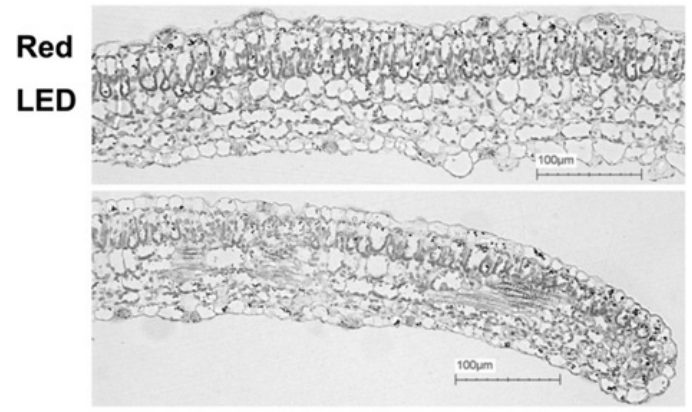

$\mathbf{R}+\mathbf{B}$

LED

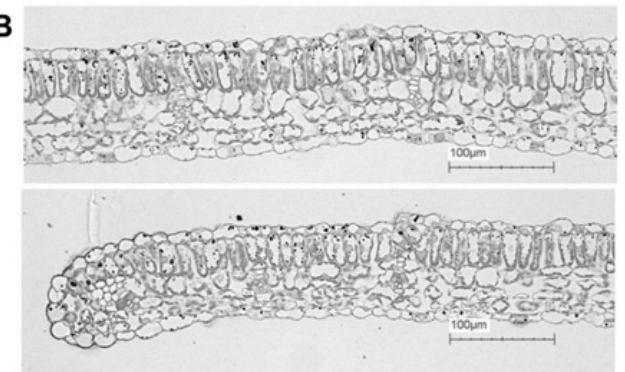

Fig. 6. Cross-sections of young upper leaves of grafted pepper transplants treated with different light qualities during the six-days healing and acclimatization period. The photosynthetic photon flux (PPF) during the healing and acclinatization period was 100 $\mu \mathrm{mol} \cdot \mathrm{m}^{-2} \cdot \mathrm{s}^{-1}$. FL, fluorescent lamps; pa, palisade tissue cells; sp, sponge tissue cells; la, lacunae. 
of Puerarialobata (Willd) Ohwi. was greater in redlight at lower light intensities $\left(175 \mu \mathrm{mol} \cdot \mathrm{m}^{-2} \cdot \mathrm{s}^{-1}\right)$ but slightly lower at high light intensities $\left(500 \mu \mathrm{mol} \cdot \mathrm{m}^{-2} \cdot \mathrm{s}^{-1}\right)$. In rice, the photosynthesis under red LEDs was also lower than under red + blue LEDs (Matsuda et al., 2004). The difference in the photosynthesis between the light treatments of red and red + blue LEDs was greater under higher PPF conditions. In this study, the increase in the $\mathrm{CO}_{2}$ exchange rates of grafted pepper transplants by higher PPFs was lower under red LEDs. Light quality may affect light compensation or the saturation point and light-limited or light-saturated photosynthetic rates (Fig. 3).

These different photosynthetic responses were attributed to changes in stomatal development and behavior as well as the structure and chlorophyll content in leaves (Hogewonign et al., 2010; Liu et al., 2011; Tennessen et al., 1994).Leaves of cherry tomato irradiated with spectra containing blue light were reported to be thicker, have well-developed structure in the palisade tissue cells, and have more stomata (Liu et al, 2011). Tennessen et al. (1994) suggested that monochromatic red light caused an imbalance in the available light energy required for optimal functioning of photosystems I and II.

Kim et al. (2004) reported that the $\mathrm{CO}_{2}$ assimilation rates of a single leaf at a single point could not fully explain the effect of light quality on dry weight accumulation. They suggested that diurnal net photosynthesis and dark respiration measurements of single leaves or whole canopies would be useful in order to determine the fate of carbon in plants grown under different qualities of light. In this study, the $\mathrm{CO}_{2}$ exchange rates of whole pepper transplants were measured continuously during the six day healing and acclimatization period (Fig. 3). Right after grafting, the $\mathrm{CO}_{2}$ exchange rates during the light period were near zero and increased as time passed. The $\mathrm{CO}_{2}$ exchange rates during the dark period were very low (approximately $-2 \mu \mathrm{mol} \mathrm{CO}_{2} \cdot \mathrm{m}^{-2} \cdot \mathrm{s}^{-1}$ ) on the first day, but they were constant thereafter (about $-1 \mu \mathrm{mol} \mathrm{CO} \cdot \mathrm{m}^{-2} \cdot \mathrm{s}^{-1}$ ). At a PPF of $50 \mu \mathrm{mol} \cdot \mathrm{m}^{-2} \cdot \mathrm{s}^{-1}$, the photosynthetic rates during the light period and there spiration rates during the dark period were almost the same. As the PPF increased, the photosynthetic rates increased, but the respiration rates remained constant. These responses to light intensity were considered to influence the RGRs of the grafted pepper transplants. At a PPF of $50 \mu \mathrm{mol} \cdot \mathrm{m}^{-2} \cdot \mathrm{s}^{-1}$, the RGRs were near zero and eventually increased as the PPF increased (Table 4).

The grafted pepper transplants irradiated with red LEDs showed low photosynthesis rates and had low leaf area, leaf dry weight, and dry matter content (Table 3 ). The SPAD value of the leaves was also low. These results correspond to the inferior photosynthetic ability shown in the $\mathrm{CO}_{2}$ exchange rates for red LEDs versus other light treatments. Macedo et al. (2011) reported that the growth parameters, including specific leaf mass, thickness, leaf density, and leaf area, of Alternanthera brasiliana Kuntze were lowest in plants grown under red light. Goins et al. (1997) also reported that wheat grown under red LEDs alone had significantly lower amounts of dry matter than when other light treatments were used. They suggested that the lower dry matter accumulation in wheat grown under red LEDs alone might be related to the lower $\mathrm{CO}_{2}$ assimilation rate.

Amaki and Hirai (2008) classified horticultural crops into two types according to hypocotyl or stem internode elongationin response to monochromatic light (red alone or blue alone). The first type was where the stem internode irradiated with red light was longer than that irradiated with blue light and the elongation was inhibited by blue light. Lettuce, tomato, radish, and chrysanthemum were reported to belong to this first type. The second type was where the stem internode irradiated with blue light was longer than that irradiated with red light and the elongation was inhibited by red light. Eggplant, sunflower, broccoli, rose, and pepper were reported to belong to this second type. The inhibition of stem internode elongation by red light is theoretically mediated by phytochrome, red-light photoreceptors, and the inhibition by blue light is supposed to be mediated by cryptochrome, blue-light photoreceptors. In this study, the shoot length of the grafted pepper transplants irradiated with blue LEDs was longer than those irradiated using other treatments. The stem fresh weight was also greater under blue LEDs.

Under red LEDs, the young upper leaves became abaxially curled (epinastic). The epinasty became more pronounced over time and under higher PPF conditions (Figs. 4 and 5). However, this was not the case for plants grown under blue LEDs, red + blue LEDs, or fluorescent lamps. Downward curling of the leaf margins and spiral growth of the rosette appeared in Arabidopsis plants grown only under red light. The inclusion of blue light at any level, however, restored normal leaf morphology (Massa et al., 2008). Fukuda et al. (2008) also reported that geranium leaves showed one type of epinasty under red LEDs. Under a combination lamp with red and blue LEDs, the geranium produced normally shaped leaves. Fukuda et al. (2008) proposed that the leaf epinasty in the geranium was controlled by cell elongation of the abaxial epidermis triggered by blue light irradiation and that these responses were a shade avoidance response. In their study, the length of the epidermal cells of the abaxial sides irradiated with blue light was 7 to $13 \%$ longer than those under red irradiation alone. The effect of light quality on the leaf epinasty was dependent on the light intensity. Fukuda et al. (2008) also reported that young leaves clearly responded to changes in the light quality, while older leaves that had 
already stopped growing and had no further growth capacity showed less response to the light quality.

The light quality also influenced the leaf anatomical structure (Fig. 6). The palisade and spongy cells of pepper leaves irradiated with red LEDs were dysplastic and exhibited hyperplasia. The cells were aligned more densely and there was barely any empty space (lacunae) between the spongy cells. The leaf thickness was a little bit thicker in the plants irradiated under red LEDs. This result did not agree with previous reports that the thickness of the palisade and spongy parenchyma of leaves was significantly reduced in plants grown under red light (Fukuda et al., 2008; Liu et al., 2011; Macedo et al., 2010; Schuerger et al., 1997). Smaller empty space (lacunae) in the spongy tissue in leaf, especially in plants irradiated under red LEDs, may inhibit the supply of $\mathrm{CO}_{2}$ for photosynthesis. The decrease in photosynthesis under red light seems to be related to the structure of the palisade and spongy tissue in leaves. Additional experiments need to be carried out in order to examine the structural differences in leaves grown under various types of LEDs.

In conclusion, this study showed that the light quality and intensity during the healing and acclimatization periods influenced the photosynthesis, growth, and morphology of grafted pepper transplants. Red LEDs alone decreased the photosynthesis and growth and also caused abnormal morphology in the leaves. Higher PPF levels increased the photosynthesis and growth, irrespective of light quality. The results of this suggest that high-quality grafted pepper transplants can be obtained by healing and acclimatizing plants under a combination of red and blue light and high PPF levels.

\section{Literature Cited}

Amaki, W. and T. Hirai. 2008. Photomorphogenic responses of horticultural crops to monochromatic light, p. 29-40. In: E. Goto (ed.). Agri-photonics-Advances in plant factories with LED lighting. CMC Press, Tokyo, Japan (in Japanese)

Brown, C.S., A.C. Schuerger, and J.C. Sager. 1995. Growth and photomorphogenesis of pepper plants under red light-emitting diodes with supplemental blue or far-red lighting. J. Amer. Soc. Hort. Sci. 120:808-813.

Fang, W. and R.C. Jao. 2000. A review on artificial lighting of tissue cultures and transplants, p. 108-113. In: C. Kubota and C. Chun (eds.). Transplant production in the $21^{\text {st }}$ century. Kluwer Academic Publishers, Dordrecht, The Netherlands.

Fukuda, N., M. Fujita, Y. Ohta, S. Sase, S. Nishimura, and H. Ezura. 2008. Directional blue light irradiation triggers epidermal cell elongation of abaxial side resulting in inhibition of leaf epinasty in geranium under red light condition. Sci. Hort. 115:176-182.

Goins, G.D., N.C., Yorio, M.M. Sanwo, and C.S. Brown. 1997. Photomorphogenesis, photosynthesis, and seed yield of wheat plants grown under red light-emitting diodes (LEDs) with and without supplemental blue lighting. J. Exp. Bot. 48:1407-1413.

Goto, E. 2011. Application of artificial light sources for plant production. J. Illuminating Eng. Inst. Japan 95:200-204. (in Japanese with English abstract)

Hogewonign, S.W., G. Trouwborst, H. Maljaars, H. Poorter, W. van Ieperen, and J. Harbinson. 2010. Blue light dose-responses of leaf photosynthesis, morphology, and chemical composition of Cucumissativus grown under different combinations of red and blue light. J. Exp. Bot. 61:3107-3117.

Jang, Y.A., E. Goto, Y. Ishigami, B.H. Mun, and C.H. Chun. 2011. Effects of light intensity and relative humidity on photosynthesis, growth and graft-take of grafted cucumber transplants during healing and acclimatization. Hort. Environ. Biotechnol. 52:331-338.

Kim, H.H., F.D. Goins, R.M. Wheeler, and J.C. Sager. 2004. Green-light supplementation for enhanced lettuce growth under red and blue-light-emitting diodes. HortScience 39:1617-1622

Lee, J.G., S.S. Oh, S.H. Cha, Y.A. Jang, S.Y. Kim, Y.C. Um, and S.R. Cheong. 2010. Effects of red/blue light ratio and short-term light quality conversion on growth and anthocyanin contents of baby leaf lettuce. J. Bio-Environ. Cont. 19:351-359.

Lee, J.M., and M. Oda. 2003. Grafting of herbaceous vegetable and ornamental crops. Hort. Rev. 28:61-121.

Liu, X., S. Guo, Z. Xu, and X. Jiao. 2011. Regulation of chloroplast ultrastructure, cross-section anatomy of leaves, and morphology of stomata of cherry tomato by different light irradiations of light emitting diodes. HortScience 46:217-221.

Louws, F.J., C.L. Rivard, and C. Kubota. 2010. Grafting fruiting vegetables to manage soilborne pathogens, foliar pathogens, arthropods and weeds. Sci. Hort. 127:127-146.

Luft, J.H. 1973. Embedding media-old and new, p. 1-34. In: J.K Koehler (ed.). Advance techniques in biological electron microscopy. Springer-Verlag, Berlin and New York.

Macedo, A.F., M.V. Leal-Costa, E.S. Tavares, C.L.S. Lage, and M.A. Esquibel. 2011. The effect of light quality on leaf production and development of in vitro-cultured plants of Alternantherra brasilianan Kuntze. Environ. Experimental Botany 70:43-50.

Massa, G.D., H.H. Kim, R.M. Wheeler, and C.A. Mitchell. 2008. Plant productivity in response to LED lighting. HortScience 43:1951-1953

Matsuda, R., K. Ohashi-Kaneko, K. Fujiwara, E. Goto, and K. Kurata. 2004. Photosynthetic characteristics of rice leaves grown under red light with or without supplemental blue light. Plant cell Physiol. 45:1870-1874.

McNellis, T.W. and X.W. Deng. 1995. Light control of seedling morphogenetic pattern. Plant Cell 7:1749-1761.

Mun, B.H., Y.A. Jang, E. Goto, Y. Ishigami, and C.H. Chun. 2011. Measurement System of whole-canopy dioxide exchange rates in grafted cucumber transplants in which scions were exposed to different water regimes using a semi-open multichamber. Sci. Hort. 130:607-614.

Nobuoka, T., T. Nishimoto, and K. Toi, 2005. Wind and light promote graft-take and growth of grafted tomato seedlings. J. Japan. Soc. Hort. Sci. 74:170-175. (in Japanese with English abstract)

Savvas, D., G. Colla, Y. Rouphael, and D. Schwarz. 2010. Amelioration of heavy metal and nutrient stress in fruit vegetables by 
grafting. Sci. Hort. 127:156-161.

Schuerger, A.C., C.S. Brown, and E.C. Stryjewski. 1997. Anatomical features of pepper plants (Capsicum annuum L.) grown under red light-emitting diodes supplemented with blue or far-red light. Ann. Bot. 79:273-282.

Schwarz, D., Y. Rouphael, G. Colla, and J.H. Venema. 2010. Grafting as a tool to improve tolerance of vegetables to abiotic stresses: Thermal stress, water stress and organic pollutants. Sci. Hort. 127:162-171.

Shibuya, T., J. Tsuruyama, Y. Kitaya, and M. Kiyota. 2006. Enhancement of photosynthesis and growth of tomato seedlings by forced ventilation within the canopy. Sci. Hort. 109:218-222.
Shibuya, T. and T. Kozai. 1998. Effects of air current speed on net photosynthetic and evapotranspiration rates of a tomato plug sheet under artificial light. Environ. Control Biol. 36:131-136.

Tennessen, D.J., E.L. Singsaas, and T.D. Sharkey. 1994. Lightemitting diodes as a light source for photosynthesis research. Photosynth. Res. 39:85-92.

Yorio, N.C., G.D. Goins, and H.R. Kagie. 2001. Improving spinach, radish, and lettuce growth under red light-emitting diodes (LEDs) with blue light supplementation. HortScience 36:380-383.

van Iersel, M.W. and B. Bugbee. 2000. A multi-chamber, semicontinuous, crop carbon dioxide exchange system: Design, calibration, and data interpretation. J. Amer. Soc. Hort. Sci. 125:86-92. 